\title{
Physical factors and biological interactions regulating infauna in shallow boreal areas
}

\author{
Peter Möller*
}

Institute of Marine Research, Lysekil, Sweden

\begin{abstract}
Infauna, including all post-larval stages, were quantitatively sampled from 1977 to 1984 in a shallow $(<1 \mathrm{~m})$ unvegetated, semi-exposed soft bottom area, situated on the Swedish west coast. Variations in the infaunal abundance, biomass and production are shown to be the result of temperature conditions and predator-prey interactions. Temperature is considered to be an important physical factor causing annual and seasonal variations in spat recruitment, biomass and survival over the winter. During the post-recruitment period, infaunal abundances are mainly controlled by intra- and interspecific competition, particularly the predation of mobile epibenthic animals. Intra- and interspecific interactions between adult bivalves and spat, as demonstrated in experimental studies, showed that high adult survival inhibited spat recruitment. In the absence of overwintered adults, spat survival increased. Interspecific interactions between adult bivalves showed that late-arriving species are able to eliminate older established species. The importance of physical factors, e.g. exposure, water depth and currents, in determining variations in the abundance, biomass and production of infauna, is also discussed. Results suggest that both abiotic factors and biological interactions are important regulating mechanisms for infaunal densities in shallow unvegetated boreal areas.
\end{abstract}

\section{INTRODUCTION}

For many years ecological studies on marine softbottoms in general have emphasized the role of physlcal factors in determining infaunal variations (Petersen 1918, Thorson 1957, Hulings \& Gray 1976). Many recent ecological studies, however, have paid more attention to the influence of biological interactions and these may include factors such as predation (Virnstein 1977, 1978, 1979, Peterson 1979, Ambrose 1984, Weinberg 1984, Pihl 1985), competition for space (Woodin 1974, Levinton 1977, Peterson 1979, Peterson \& Andre 1980, Whitlatch 1980), competition for food (Fenchel \& Kofoed 1976, Young \& Young 1978) and adult interference with larval settlement (Segerstråle 1962, Woodin 1976, Williams 1980, Peterson 1982). Most of the investigations mentioned above were carried out in intertidal areas by manipulative field experiments. The present investigation was made in unmanipulated study areas having a tidal amplitude of only $0.1 \mathrm{~m}$.

The abundance, biomass and production of the infaunal species Corophium volutator (Pallas), Mya

\footnotetext{
- Present address: Bohuslän Museum, Box 34, S-451 15 Uddevalla, Sweden
}

arenaria L., Cardium (= Cerastoderma) edule L. and Nereis diversicolor O. F. Müller in shallow Swedish waters have been described in previous publications (Möller \& Rosenberg 1982, 1983, Möller 1985).

In this paper the role of physical and biological processes in structuring infaunal abundance, biomass and production will be analysed. The results discussed are derived from quantitative field investigations made over several years which included simultaneous studies of the infauna and the mobile epibenthic fauna. Thus it is possible to demonstrate the significance of predator-prey interactions in the natural habitat. All post-larval sizes of the 2 faunal categories were included in the sampling regime, thus adult-juvenile interactions were fully explored. Inclusion of the smallest post-larvae and individuals is essential to a detailed study of recruitment and survival in infaunal populations, since 96 to $97 \%$ of all molluscs and about $70 \%$ of polychaetes start their benthic life as members of the smaller $(<0.5 \mathrm{~mm})$ meiofauna (Thorson 1966).

Most of the interannual data derive from the unvegetated semi-exposed Gullmarsvik (Area 6: Fig. 1) on the Swedish west coast studied between 1977 and 1984 and additional results are presented from other shallow water habitats, which reflect the influence on the 
infauna of such physical factors as exposure and sediment composition.

\section{AREAS STUDIED}

In this study 13 shallow unvegetated areas and 2 vegetated were investigated on the Swedish west coast (Fig. 1). According to exposure, organic content in the sediment and presence of vegetation, the areas were grouped into 4 habitat categories (Table 1). These

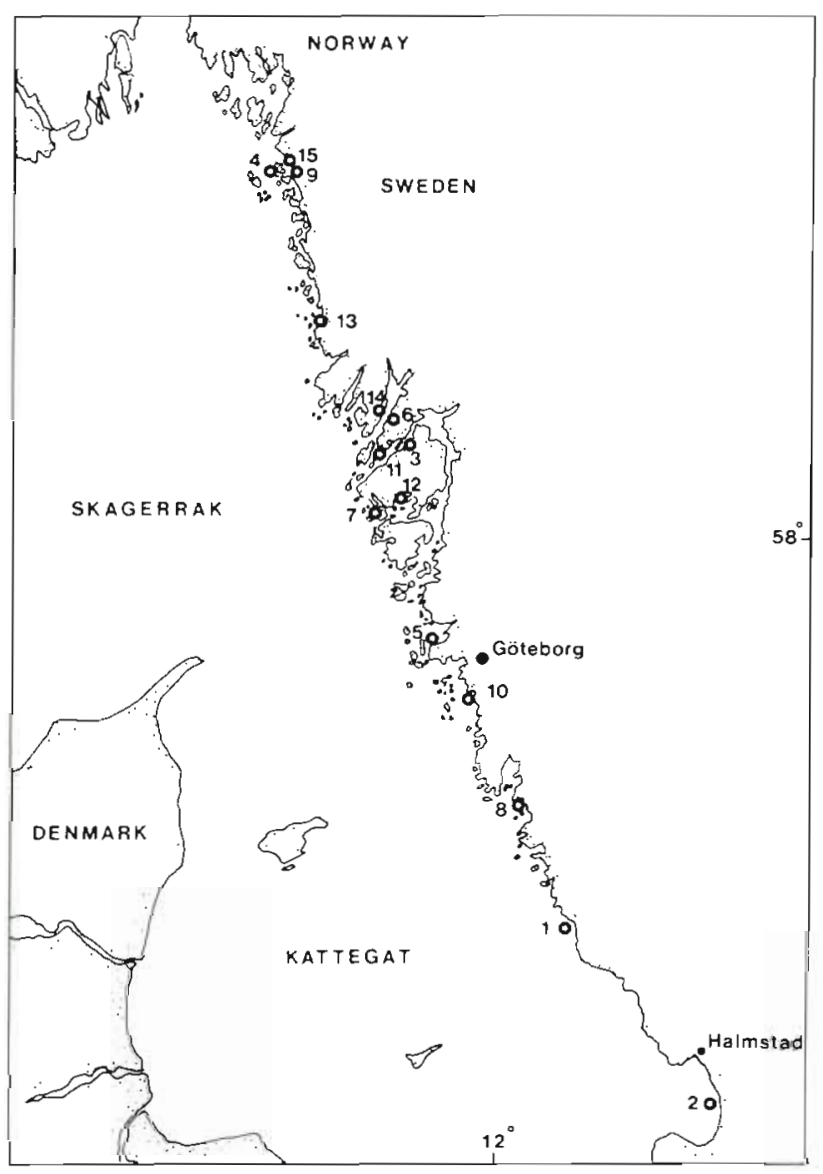

Fig. 1. Map showing location of areas investigated

were: (1) exposed, (2) semi-exposed and (3) sheltered areas situated between 0 and $1 \mathrm{~m}$ water depth with almost no vegetation, and (4) vegetated meadows dominated by Zostera marina (L.) from 1 to $3 \mathrm{~m}$ depth. Each habitat category was investigated in at least 2 different regions. Areas 1, 5, 6, 11 and 14 were intensively sampled (in some months every week) over a period of 2 to $8 \mathrm{yr}$ between 1977 and 1984. Remaining areas were sampled during 'survey studies' in June and September 1981 and/or 1982.

Areas studied had a seasonal mean water temperature variation from below zero in most winters to about $18^{\circ} \mathrm{C}$ in summer (Fig. 2). During the investigation period from 1977 to 1984, about half of Gullmarsvik was normally covered with ice from December to March and in sheltered parts of this area temperature maxima in summer could reach extremes of above $25^{\circ} \mathrm{C}$ on sunny days. Salinity normally fluctuated around $20 \%$ with extremes of 1 and $30 \%$ in the areas along the Skagerrak coast, while salinity in the Kattegat was normally somewhat lower because of the influence of Baltic water. The tidal amplitude was about $0.1 \mathrm{~m}$, but high air pressures could occasionally cause prolonged exposure of the study areas.

\section{METHODS}

In unvegetated areas of 1 to 4 hectares each, infauna was quantitatively sampled at random using cores of various sizes $\left(16,87\right.$ or $\left.290 \mathrm{~cm}^{2}\right)$. Sampling precision was maintained by taking 20 to 40 samples on each sampling occasion, which resulted in a standard error usually $<30 \%$ of the mean. During the recruitment period, when the abundance was high and the animals were small, the $16 \mathrm{~cm}^{2}$ corer was used. In autumn and spring, when the animals were usually fewer and larger, the $87 \mathrm{~cm}^{2}$ corer was used. The $290 \mathrm{~cm}^{2}$ corer was used to follow the development of large overwintering adults of Mya arenaria and Cardium edule. During the recruitment period all of the upper $5 \mathrm{~cm}$ of sediment was decanted and sieved through $0.2 \mathrm{~mm}$ meshes and animals were analysed and measured under a stereomicroscope. When investigating older animals with the larger corers, sieves of 0.5 or $1.0 \mathrm{~mm}$ were used. Biomass was calculated as unpreserved ash-free dry weight (ADW) from length-weight relations (Möller \& Rosenberg 1982, 1983, Möller 1985). Samples from the Zostera meadows were taken by diving, using an $87 \mathrm{~cm}^{2}$ core. Samples were sieved through $0.5 \mathrm{~mm}$ meshes.

Organic content in the sediment $(0$ to $5 \mathrm{~cm})$ was obtained after drying to constant weight at $60^{\circ} \mathrm{C}$ and then combusting for $5 \mathrm{~h}$ at $550{ }^{\circ} \mathrm{C}$. Exposure was calculated as effective fetch $(\mathrm{km})$ (Håkanson \& Jansson 1983).

Abundance, biomass and production of dominant infauna are given in Möller \& Rosenberg $(1982,1983)$ and Moller (1985); estimates of food selection and consumption of mobile epibenthic fauna and migratory fish are from Pihl $(1982,1985)$ and Pihl \& Rosenberg (1984). Change in abundance and biomass of the infauna along a depth transect from 1 to $10 \mathrm{~m}$ were studied by divers, who took two 0 to $10 \mathrm{~cm}$ sediment samples using an $87 \mathrm{~cm}^{2}$ core, at $1 \mathrm{~m}$ depth intervals. These were sieved through $0.5 \mathrm{~mm}$ meshes.

The movement of spat in and out of 2 sites at $1 \mathrm{~m}$ 


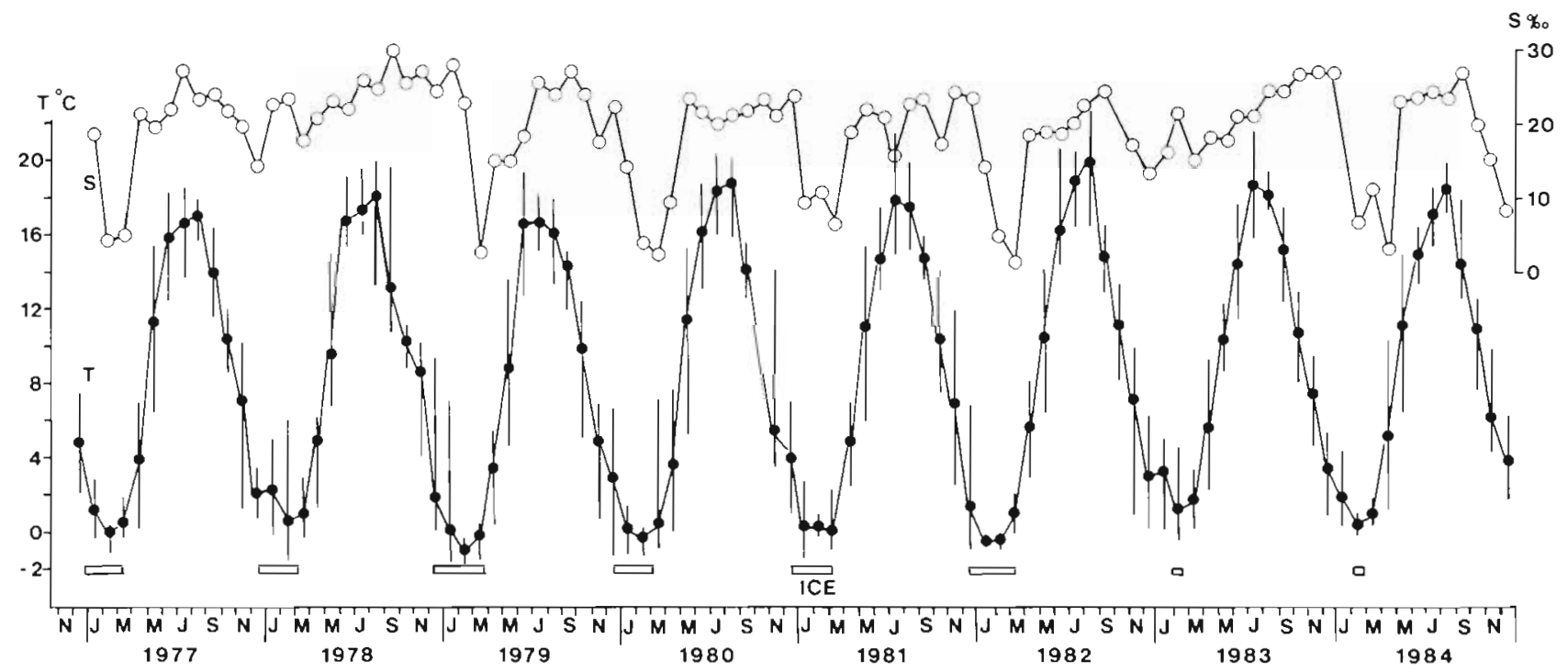

Fig. 2. Monthly means of surface salinity (top) and water temperature (bottom) with maximum and minimum ranges from the Gullmarsfjord at Bornö Hydrographical Station. Periods of ice in Gullmarsvik are indicated

depth in Gullmarsvik was studied. Spat was caught in $125 \mu \mathrm{m}$ plankton nets set at 0 to $20 \mathrm{~cm}$ and 20 to $40 \mathrm{~cm}$ above the bottom. At each site 2 nets were set out; one with the open mouth facing inwards and the other facing outwards towards the mouth of the bay. The openings were $20 \times 15 \mathrm{~cm}$. These experiments lasted for $24 \mathrm{~h}$

Aluminium cages for predation exclosure experiments were $70 \times 70 \mathrm{~cm}$ and $15 \mathrm{~cm}$ high covered with $1 \mathrm{~mm}$ nylon meshes. On each sampling occasion, 3 to 6 cores $\left(16 \mathrm{~cm}^{2}\right.$ each) were taken to $5 \mathrm{~cm}$ depth and sieved through 0.2 or $0.5 \mathrm{~mm}$ meshes. In order not to cause excessive disturbance in the exclosure experiments where adult-juvenile bivalve interactions were studied, areas having natural abundances of 0,10 and 100 adult Mya arenaria per $0.5 \mathrm{~m}^{2}$ were used. Abundances were estimated by counting the siphons several times before the start of experiments.

\section{RESULTS AND DISCUSSION}

\section{Seasonality in infaunal species caused by physical factors}

\section{Exposure}

In the exposed, high wave energy sandy areas in the Kattegat, the number of species, abundance and biomass appeared to be lowest of all areas investigated (Fig. 3; Table 1). In all the exposed areas the species Bathyporeia sarsi Watkin, Nereis diversicolor, Pygospio elegans Claparède, Cardium edule and Mya arenaria together contributed about 70 to $90 \%$ of the total infaunal biomass. All these species, with the exception of $B$. sarsi, can act as filter feeders and this trophic group thus dominates the biomass in the sandy exposed areas. The omnivorous $N$. diversicolor and the versatile $P$. elegans, often considered as a surface deposit feeder, are also capable of filter feeding with the aid of mucous nets within their tubes (Fauchald \& Jumars 1979).

In the exposed areas of the Skagerrak, the shallow infaunal assemblages were richer, both in terms of the number of species, number of individuals and biomass, than those of the Kattegat (Fig. 3; Table 1). This was most probably a consequence of the protection obtained from a surrounding archipelago, i.e. the areas in the Skagerrak were less exposed to wind than areas in the Kattegat.

In the unvegetated semi-exposed and sheltered habitats, the total infaunal biomass before bivalve recruitment at the end of June was made up in general by 5 dominants: Nereis diversicolor, Corophium volutator, Pygospio elegans, Hydrobia spp. and oligochaetes. Following the recruitment of the spat in the semi-exposed habitats, $N$. diversicolor, $C$. volutator and oligochaetes were of less importance, and Mya arenaria and Cardium edule assumed a much greater importance. However, the total biomass varied considerably between years, probably according to the relative success of spat recruitment and survival.

The highest infaunal diversity (including some epifaunal amphipods and polychaetes) was found in vegetated Zostera marina habitats (Table 1). Oligochaetes and chironomids, the amphipods Ericthonius spp. and Microdeutopus gryllotalpa (Costa), and to a certain extent the polychaete Nereis diversicolor were the numerically dominant species during the year. However, most of the species were abundant for only brief 


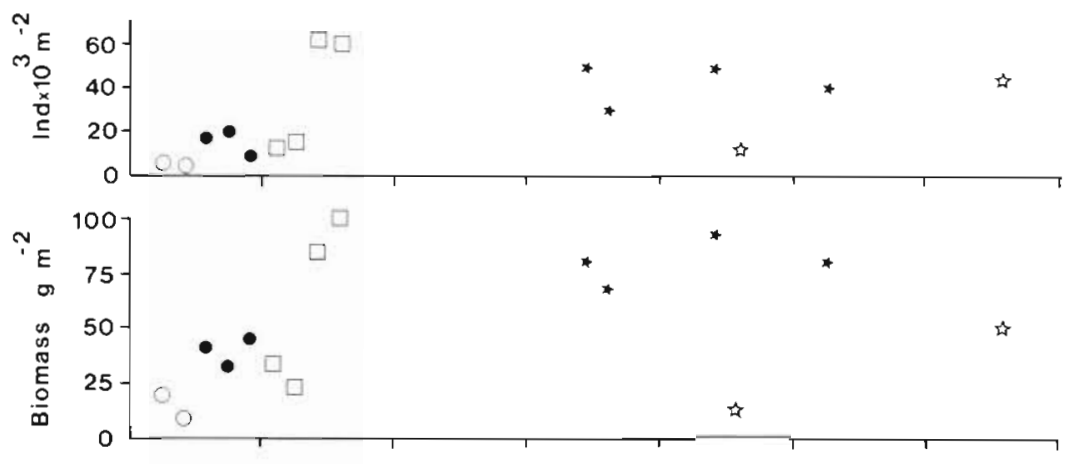

Fig. 3. Infaunal sampling survey in September along the Swedish west coast showing numbers of individuals $\mathrm{m}^{-2}$ (top), biomass $\mathrm{g}$ wet weight $\mathrm{m}^{-2}$ (middle) and feeding category as percent of biomass (bottom). Areas are rank-

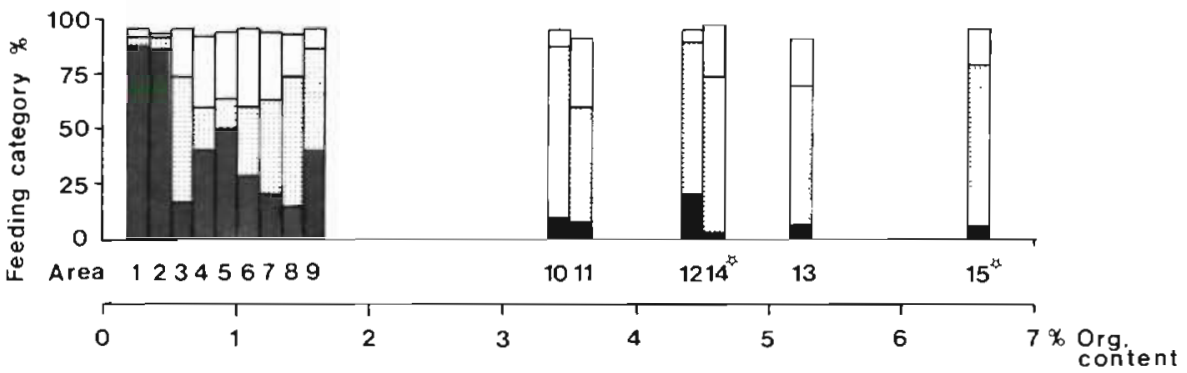
ed according to the organic content in the sediment. (O) exposed areas in the Kattegat; (•) exposed areas in the Skagerrak; ( $\square$ ) semiexposed, and ( $\star$ ) sheltered areas in the Skagerrak; (c) vegetated areas. Bars: shaded, filter feeders; stippled, deposit feeders; open, Nereis diversicolor and Pygospio elegans

Table 1. Exposure (effective fetch, $\mathrm{km}$ ), organic content in sediment (\%), total number of infauna species, mean number of total individuals $\mathrm{m}^{-2}$ (with $\mathrm{SE}$ ), total mean biomass $\left(\mathrm{g} \mathrm{ADW} \mathrm{m}^{-2}\right.$ ) and annual production $\left(\mathrm{g} \mathrm{ADW} \mathrm{m}^{-2}\right.$ ) of the 0 -groups or of all year classes of Nereis diversicolor, Corophium volutator, Mya arenaria and Cardium edule in exposed areas in the Kattegat and the Skagerrak, and in semi-exposed, sheltered and vegetated areas in the Skagerrak

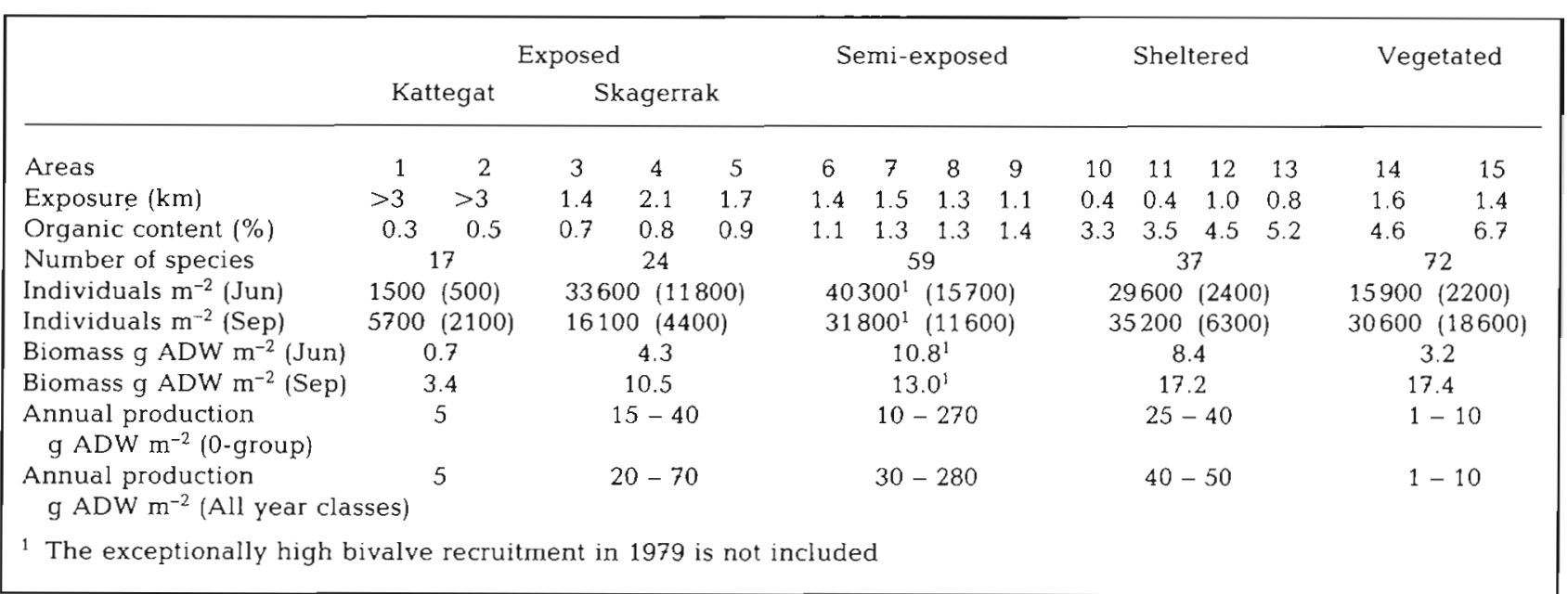

periods which usually occurred immediately following recruitment. Similar short-duration peaks were also found by Marsh (1973) when studying the epifauna in an eelgrass bed in Virginia, USA, where fluctuations were related to either reproductive or migratory activities. Predation from mobile epibenthic fauna must also be considered, as proposed by Young et al. (1976), Young \& Young (1977) and Nelson (1980).

Infaunal communities in vegetated areas are usually found to exhibit higher densities and biomass values than nearby unvegetated areas (Santos \& Simon 1974, Orth 1977, Reise 1978, Stoner 1980, Summerson \& Peterson 1984). This was not the case in this study, as number of individuals and biomass were highest in sheltered and semi-exposed areas in the summer and about the same in these 3 habitats (semi-exposed, sheltered, vegetated) in the autumn. One eelgrass meadow (Area 14), had an annual mean infaunal abundance of about 16000 ind $\mathrm{m}^{-2}$, with a range of about 3000 to 27000 ind $\mathrm{m}^{-2}$, i.e. abundances equal to those reported by Orth (1973) and Marsh (1973), but higher than found by Young et al. (1976), Stoner (1980) and Lewis \& Stoner (1983). Orth (1973) and Young et al. (1976) used a $1 \mathrm{~mm}$ sieve, the others $0.5 \mathrm{~mm}$ sieves. Diversity and biomass values in vegetated areas were in general lower in this study than ir those cited above. 
However, variations of diversity and biomass values in different regions would be expected, as the importance of physical factors and biological interactions (see below) may vary with the particular habitat investigated. Diversity of amphipods has for instance been shown to increase significantly with decreasing latitude (Virnstein et al. 1984).

The infauna community of eelgrass beds in the Skagerrak was dominated by deposit and non-suspension species. These constituted 70 to $95 \%$ of the total infauna.

Annual production of the dominant species (Fig. 4 ;

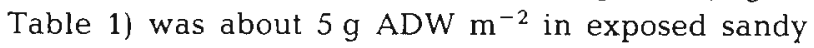
areas in the Kattegat and 20 to $70 \mathrm{~g}$ in exposed areas in the Skagerrak. In sheltered and semi-exposed areas in the Skagerrak production varied from 40 to 50 and 23 to $273 \mathrm{~g} \mathrm{ADW} \mathrm{m}^{-2}$ respectively, while vegetated areas had a production of 1 to $10 \mathrm{~g} \mathrm{ADW} \mathrm{m}^{-2}$. In all areas an annual production above $50 \mathrm{~g} \mathrm{ADW} \mathrm{m}^{-2}$ was due to high recruitment or good survival of the bivalves $M y a$ arenaria and/or Cardium edule. Production and production capacity of the dominant infauna in the areas investigated were in general found to be higher than in the Wadden Sea and in highly productive intertidal mud flats (Möller \& Rosenberg 1982, 1983).

In conclusion, exposure is an important parameter in explaining the variation of production in shallow areas. Unvegetated semi-exposed areas on the west coast of Sweden, with a sediment organic content of 1.0 to $1.5 \%$, in general exhibit the highest biomass and production values of the areas examined. With increasing organic content in the sediment, the deposit feeder category increases at the expense of suspension feeders. Vegetated areas showed the highest infaunal diversity of all areas.
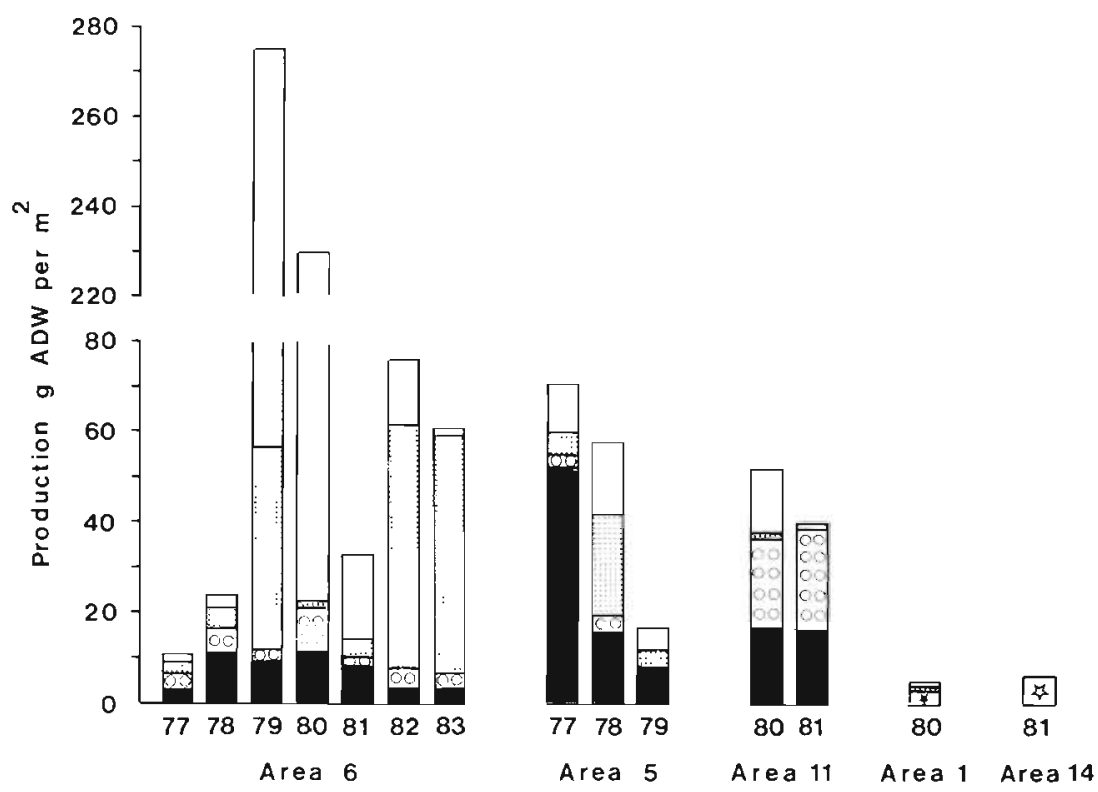

Fig. 4. Annual production (g ADW $\mathrm{m}^{-2}$ ) of dominant infauna in a semi-exposed area (6), an exposed area in the Skagerrak (5), a sheltered area (11), an exposed area in the Kattegat (1) and a vegetated area (14). Production is calculated for all year classes and as a mean value for the whole area. Bars: shaded, Nereis diversicolor; with circles, Corophium volutator; stippled, Cardium edule; open, Mya arenaria; ( $\star$ Bathyporeia pilosa + B. sarsi; ( $\Leftrightarrow$ ) various species 


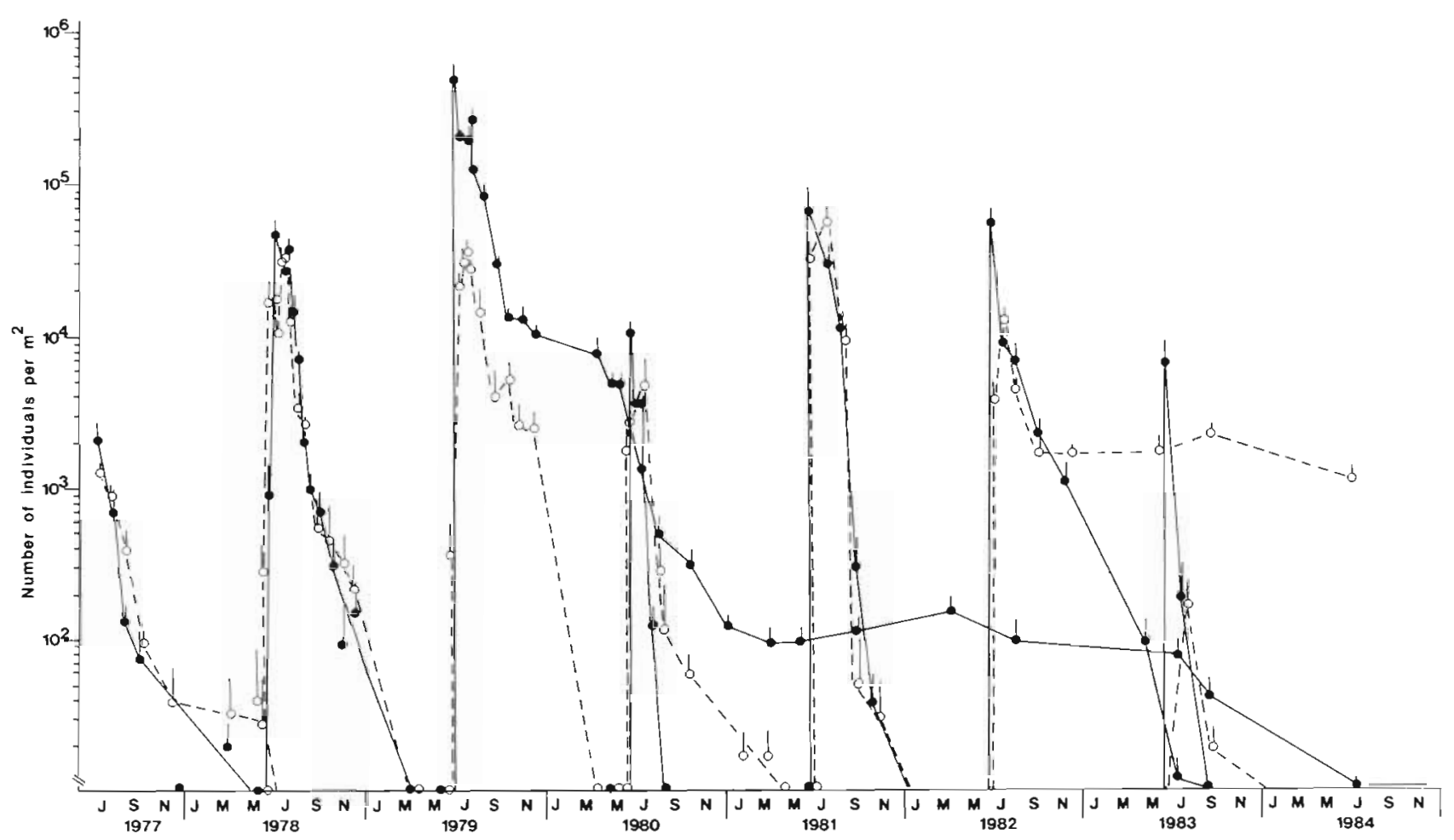

Fig. 5. Mya arenaria (๑) and Cardium edule (O). Mean abundance (ind $\mathrm{m}^{-2}$ with SE) of bivalves in the outer area (50 to $100 \mathrm{~cm}$ water depth) of Gullmarsvik from 1977 to 1984

parts of northern Europe considered the most severe of the past 15 yr (Beukema 1979, Arntz \& Rumohr 1982, Möller \& Rosenberg 1982). In the Gullmarsfjord the mean water temperature was $-0.2^{\circ} \mathrm{C}$ from January to March and in Gullmarsvik ice appeared from December to March. Consequently, only a few large deep-dwelling Nereis diversicolor were found in the sediment in April 1979 and the returning overwintered population of Corophium volutator was also reduced compared to other years (Möller \& Rosenberg 1982). Later, in June, an exceptionally heavy recruitment of Mya arenaria occurred on this sparsely populated bottom, with a mean of almost 500000 ind $\mathrm{m}^{-2}$ at 50 to $100 \mathrm{~cm}$ water depth (Fig. 5), i.e. an 8-fold increase compared to spat recruitment in years following a normal winter (Table 2). This year class could still be followed in 1984. Recruitment of juvenile $N$. diversicolor was also higher, with a 10 -fold increase compared to normal years. In contrast, development of the first $C$. volutator generation was poor, a consequence of either high predation from the mobile epibenthic fauna (see below) and/or the cold winter. Mortalities of infauna in shallow areas due to severe winters have also been reported from other areas, e.g. the Danish Wadden Sea (Smidt 1944) and the Dutch Wadden Sea (Kreger 1940, Beukema 1982). In these investigations the elimination of bivalves in winter was later followed by a high recruitment of bivalve spat.

Mean water temperature in the Gullmarsfjord from January to March in 1983 and 1984 was 2.3 and $1.2^{\circ} \mathrm{C}$,

Table 2. Maximum mean abundance of juvenile recruitment per $\mathrm{m}^{2}$ (with SE) of dominant infauna species following winters with mean temperature normal, mean temperature below average, and mean temperature above average during the period Jan to Mar in Gullmarsvik $1977-1984$

\begin{tabular}{|c|c|c|c|}
\hline Species & $\begin{array}{l}\text { Mean temperature normal } \\
\qquad\left(0.2-0.9^{\circ} \mathrm{C}\right)\end{array}$ & $\begin{array}{c}\text { Mean temperature below } \\
\text { average }\left(-0.2^{\circ} \mathrm{C}\right)\end{array}$ & $\begin{array}{c}\text { Mean temperature above } \\
\text { average }\left(1.2-2.3^{\circ} \mathrm{C}\right)\end{array}$ \\
\hline Mya arenaria & $58200(9000)$ & $457500(98300)$ & $7200(1900)$ \\
\hline Cardium edule & $34900(16500)$ & $37100(8200)$ & $180(80)$ \\
\hline Nereis diversicolor & $3200(1300)$ & $33000(9400)$ & $2800(1100)$ \\
\hline \multicolumn{4}{|l|}{ Corophium volutator } \\
\hline 1st generation & $13500(1800)$ & $1100 \quad(300)$ & $8100(2200)$ \\
\hline 2nd generation & $9300(1400)$ & $8400(2800)$ & $9800(1700)$ \\
\hline
\end{tabular}


respectively, i.e. these years were warmer than the other years and ice appeared for only a few weeks in the most shallow parts of the areas. Young Cardium edule survived in great numbers in January to March 1983 for the first time since the start of the investigation. As the next winter also was warm, the abundance of the 1982 year class was maintained (1500 ind $\mathrm{m}^{-2}$ ) at 50 to $100 \mathrm{~cm}$ water depth from October 1982 until July 1984 (Fig. 5). Recruitment of juvenile Nereis diversicolor and Corophium volutator approached the same level as after normal winters, while the recruitment of the bivalves Mya arenaria and $C$. edule decreased dramatically due to biological competition (Fig. 5; Table 2) which will be discussed later.

In conclusion, temperature is an important physical factor causing annual and seasonal variations in e.g. spat recruitment and survival over the winter.

\section{Infaunal changes along a depth transect}

In order to study infaunal abundance and biomass changes with depth, samples were taken by divers every metre down to $10 \mathrm{~m}$ in 5 areas with different exposure. In general, abundance and biomass decreased with increasing depth in all areas investigated. In a semi-exposed area in the Skagerrak the biomass was about $3300 \mathrm{~g}$ wet weight $\mathrm{m}^{-2}$ at $1 \mathrm{~m}$ and then gradually decreased to $5 \mathrm{~m}$ (Fig. 6). From 5 to $10 \mathrm{~m}$ the biomass was only about $1 \%$ of that at $1 \mathrm{~m}$. Of the biomass at $1 \mathrm{~m}, 99 \%$ was Mya arenaria and Cardium edule.

In an exposed area in the Kattegat, however, the highest biomass and abundance were found at 4 to $6 \mathrm{~m}$ (Fig. 6) due to the high energy from wave action at shallower depths. At $6 \mathrm{~m}$ the biomass was about $1900 \mathrm{~g}$ wet weight $\mathrm{m}^{-2}$; mainly large populations of $\mathrm{Mya}$ arenaria and Cardium edule, constituting $98 \%$ of the total biomass. The maximum number of individuals was about $14000 \mathrm{~m}^{-2}$ at $4 \mathrm{~m}$ in the exposed area com- pared to the maximum of $45000 \mathrm{~m}^{-2}$ at $1 \mathrm{~m}$ in the semi-exposed area. The organic content of the sediment was less than $1 \%$ of the dry weight down to $10 \mathrm{~m}$ in the exposed area, while it increased with depth to about $4.5 \%$ at $8 \mathrm{~m}$ in the semi-exposed area (Fig. 6).

In conclusion, the infaunal biomass is considerably higher in shallow waters $(<1 \mathrm{~m})$ than in deeper waters ( 2 to $10 \mathrm{~m}$ ); an exposed beach in Kattegat proved to be an exception, with maximal infaunal biomass at 4 to $6 \mathrm{~m}$.

\section{Currents}

In shallow areas, wind-driven turbulence is likely to result in the translocation of animals living in the surface sediment. The effects of such displacements have rarely been considered in previous investigations evaluating production or abundance of infauna.

Beukema (1973) considered direct spatfall from settling larvae of Macoma balthica (L.) in the Wadden Sea to be small in comparison to a secondary spatfall occurring after the transport by tidal streams of spat which had settled and grown up elsewhere in sheltered coastal areas. When studying active or passive displacements of adult Cardium edule, however, Orton (1926), Thamdrup (1935) and Kreger (1940) could not find proof of any large displacements.

In order to evaluate the effects of wind-induced currents occurring during bivalve spat recruitment, an experiment with plankton nets was carried out in the semi-exposed Gullmarsvik. Plankton collections from nets with openings facing both into and out of the bay showed that the prevailing north and west winds gave a predominant transport inwards of juvenile bivalves, whereas winds from south and east reduced the transport inwards (Table 3). The highest inward transport of bivalve spat from water depths deeper than $1 \mathrm{~m}$ occurred on 22 June when winds from the north brought in about 82000 individuals per $\mathrm{m}$ plankton net $\mathrm{d}^{-1}$. In
Fig. 6. Infaunal abundance (ind $\mathrm{m}^{-2}$ ), biomass ( $\mathrm{g}$ WWT $\mathrm{m}^{-2}$ ) and organic content in the sediment $(0$ to $5 \mathrm{~cm})$ along a depth transect $(0.5$ to $10 \mathrm{~m})$ in a semiexposed area in the Skagerrak $(0)$ and an exposed area in the Kattegat $(\bullet)$

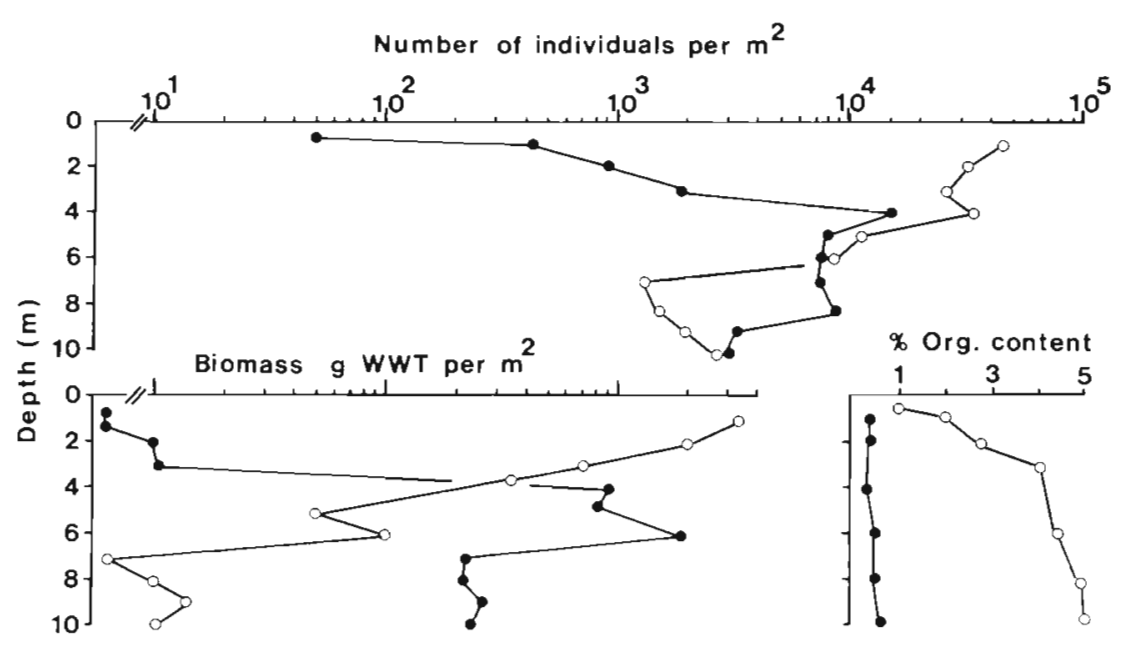


Table 3. The estimated in- and outward transport of bivalve spat obtained per m plankton net at $1 \mathrm{~m}$ water depth per $24 \mathrm{~h}$ in the western part of Gullmarsvik

\begin{tabular}{|ccccc|}
\hline Sampling date & Wind from & Force $\mathrm{m} \mathrm{s}^{-1}$ & In-transport of spat $\mathrm{m}^{-2}$ & ${\text { Out-transport of spat } \mathrm{m}^{-2}}$ \\
\hline 18 Jun 1982 & $\mathrm{NE}$ & 4 & 41200 & 30150 \\
22 Jun & $\mathrm{N}$ & 5 & 97500 & 15800 \\
23 Jun & SE & 4 & 4200 & 5100 \\
29 Jun & W & 3 & 20600 & 6100 \\
6 Jul & NW & 7 & 120000 & 48000 \\
16 Jul & SE & 6 & 4800 & 3400 \\
5 Aug & S & 3 & 400 & 500 \\
\hline
\end{tabular}

general, the incoming bivalves were caught more than $95 \%$ in nets 0 to $20 \mathrm{~cm}$ above bottom, and the rest in 20 to $40 \mathrm{~cm}$. The maximum lengths of those Mya arenaria and Cardium edule which were translocated never exceeded $2 \mathrm{~mm}$.

The highest densities of Mya arenaria and Cardium edule in Gullmarsvik were found within an area of about $4000 \mathrm{~m}^{2}$ having a water depth of 50 to $100 \mathrm{~cm}$. Within this area, $228 \times 10^{6}$ settled juvenile bivalves were found at the end of June 1982. Assuming a net inward transport of $6 \times 10^{6}$ spat $d^{-1}$ to this area, it would theoretically require $38 \mathrm{~d}$ to reach the same abundance as that obtained by random sampling 1 wk after the first recruits had arrived in the bay. Thus direct larval settlement of $M$. arenaria and $C$. edule is the dominant factor controlling recruitment of bivalves in this bay. Secondary transport of bivalve spat is also significant, however. The translocation of bivalve spat by tidal currents ought to be more important in areas like the Wadden Sea (Beukema 1973) which have large areas of shallow waters compared to most inshore Swedish waters.

It may be concluded that shallow water currents cause displacement of spat during normal weather conditions, and consequently have a minor effect on estimates of production and abundance.

\section{Seasonality of infaunal species caused by biological interactions}

\section{Predation}

The assumption is often made that predation is important in structuring the infauna in marine unvegetated soft bottom communities in the lower intertidal zone (Blegvad 1928, Muus 1973, Reise 1977a, b, 1978, Virnstein 1977, 1979). This hypothesis derives mainly from experimental results involving the removal of predators using exclusion cages. After a period of time the density of the infauna, species diversity and biomass usually changed within the cages compared to control areas. Such cages are known, however, to introduce many artifacts which are hard to control and the results are therefore often difficult to interpret (Arntz 1981).

In most years, high abundances of the dominant species (Fig. 5) during the main recruitment period were greatly reduced between July and the end of the year, when biomass approached zero. In order to evaluate the importance of predation by the epibenthic predators Crangon crangon (L.), Carcinus maenas (L.), Pomatoschistus minutus (Pallas), P. microps (Kröyer), Pleuronectes platessa L. and Platichthys flesus L., infaunal and epibenthic sampling were undertaken at the same time in the semi-exposed unvegetated Gullmarsvik from 1977 to 1979 , and the stomach contents of the epifauna were analysed (Pihl \& Rosenberg 1984, Pihl 1985).

In 1978, the biomass of juvenile Corophium volutator, Mya arenaria and Cardium edule was almost zero at the beginning of November, while there still remained about $4 \mathrm{~g}$ ADW of Nereis diversicolor. Altogether these species had a production that year (calculated for the whole area) of $23.0 \mathrm{~g} \mathrm{ADW} \mathrm{m}^{-2}$ (Table 4). According to Pihl (1985) epibenthic fauna consumed $11.3 \mathrm{~g}$ of this production. If production of the deep-burrowing $N$. diversicolor is excluded, the epibenthic fauna consumed $86 \%$ of the production of the 3 dominant infaunal species. The total consumption by epifauna of C. edule and C. volutator in 1978 was 92 and $98 \%$ of infaunal production, respectively, and of the latter species Crangon crangon consumed $57 \%$, Carcinus maenas $19 \%$, Pomatoschistus minutus $10 \%$, Pleuronectes platessa $7 \%$ and P. microps $5 \%$ (Pihl 1985). During May and June the first generation of $C$. volutator usually constituted a food resource for the overwintered C. crangon and C. maenas. In 1981, the density of the first generation of $C$. volutator was low (Fig. 6) and at the same time the highest spring abundance of $C$. crangon and $C$. maenas of all the years investigated was found, with 10 and 5 ind $\mathrm{m}^{-2}$, respectively. The following year the abundance of the first generation $C$. volutator was 100 times higher 
while the epibenthic fauna consisted of only 1 or 2 ind $\mathrm{m}^{-2}$ (Möller et al. 1985a).

The high annual production of 0-group Mya arenaria (345 $\mathrm{g} \mathrm{ADW} \mathrm{m}^{-2}$ ) and of Cardium edule $\left(73 \mathrm{~g} \mathrm{~m}^{-2}\right)$ in 1979 was probably a consequence of high settlement on unoccupied sediments denuded of organisms by the effects of the severe winter (see above) perhaps magnified by reduced predation pressure due to the late

Table 4. Annual 0-group production ( $\mathrm{g} \mathrm{ADW} \mathrm{m}^{-2} \mathrm{yr}^{-1}$ ) of dominant infauna species and annual consumption (g ADW $\mathrm{m}^{-2} \mathrm{yr}^{-1}$ ) by mobile epibenthic fauna from Gullmarsvik in

1978. In brackets: consumption as percent of production

\begin{tabular}{|lrr|}
\hline & Production & Consumption ${ }^{1}$ \\
\hline Corophium volutator & 6.3 & $6.2(98)$ \\
Nereis diversicolor & 11.2 & $1.5(14)$ \\
Mya arenaria & 3.6 & $2.2(62)$ \\
Cardium edule & 1.9 & $1.8(92)$ \\
& 23.0 & $11.7(51)$ \\
Consumption estimates from Pihl (1985) & \\
\hline
\end{tabular}

arrival and the low densities of the mobile epibenthic predators. These were delayed 1 to 2 mo in $1979 \mathrm{com}$ pared to other years (Pihl \& Rosenberg 1982), thus the first recruited bivalves had an opportunity to grow beyond the critical size for being captured by the main predators. According to stomach analyses, Crangon crangon could not eat bivalves larger than 2 to $3 \mathrm{~mm}$, while the more rarely occurring flounders (1 to 4 group) ate 10 to $12 \mathrm{~mm}$ bivalves (Pihl 1982). Consequently, due to the high bivalve production during 1979, the consumption by the epibenthic fauna was of minor importance compared to that in other years and a high density of bivalves still remained in December 1979 (Fig. 5).

In 1982, the populations of Mya arenaria and Cardium edule were again not greatly reduced before the end of the year. This could probably be related to low densities of overwintering (1-group) Crangon crangon and Carcinus maenas and of a reduced 0 -group of $C$. maenas (Möller et al. 1985a). The comparatively high survival of C. edule in 1982 could also be a result of its faster than usual growth rate which occurred from August to November (Möller \& Rosenberg 1983).

In conclusion, high mortality of infauna immediately after recruitment is mainly caused by predation by epibenthic fauna. High mortality of juvenile infauna could usually be related to high abundances of the epibenthic fauna and vice versa. In Gullmarsvik 50 to $75 \%$ of the 0 - to 1 -group infaunal annual production of 4 dominants was usually consumed by epibenthic predators (Möller et al. 1985b).

\section{Removal of predators using exclusion cages}

A small experimental program was designed to study the role of epibenthic animals as predators on the infauna. Organic content and particle size analysis of the sediment were measured before and after the experiments.

Two cages, $0.5 \mathrm{~m}^{2}$ each, were set up at the end of June and all epibenthic predators were removed from them. Although the experiment was designed to exclude large predators, the net could not prevent planktonic crab larvae recruiting into the cages in August. This settlement was later shown to have a great impact particularly on Corophium volutator (Fig. 7; Table 5). In Cage I the crabs were allowed to remain, whereas in Cage II most of the crabs were removed on 10 August. Twenty d later Cages I and II contained 96 and 25 juvenile crabs, respectively, and by the end of the experiment there were 41 and 17 . When predators were removed, the numbers of $C$. volutator increased due to newly hatched juveniles, while $C$, volutator decreased continuously in the uncaged ambient control area. Following the crab settlement, the numbers of $C$. volutator decreased at a rate approximately related to the abundance of crabs. The highest density of crabs caused a complete extinction of $C$. volutator, but about 1600 ind $0.5 \mathrm{~m}^{-2}$ remained in the cage with few Carcinus maenas and about 900 ind $0.5 \mathrm{~m}^{-2}$ in the control area.

The bivalves Mya arenaria, Cardium edule and Spisula subtruncata were found within the cages at abundances of between 4000 and 12000 ind $0.5 \mathrm{~m}^{-2}$

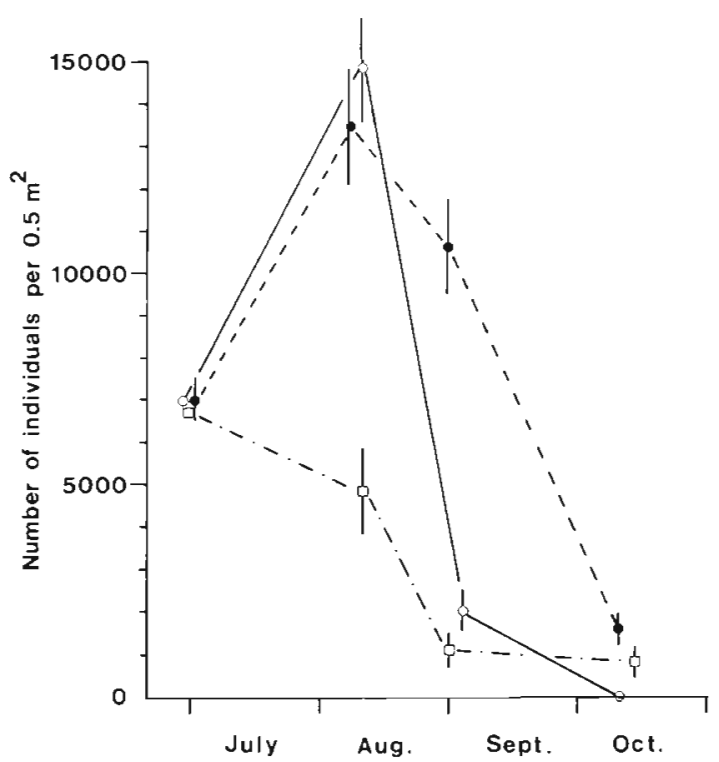

Fig. 7. Corophiun volutator. Mean abundance (ind $0.5 \mathrm{~m}^{-2}$ with SE) in Cage I $(0)$ and Cage II ( $\bullet$ and from an uncaged ambient control area ( $\square$ ). The cages excluded large predators, but not settling crab larvae 
Table 5. Mean abundance of dominant infauna species (with SE) per $0.5 \mathrm{~m}^{2}$ from 2 cages having different abundances of juvenile Carcinus maenas and from an uncaged ambient control area. Experimental time from 30 Jun to 10 Oct 1978 . C. maenas abundance described in text

\begin{tabular}{|c|c|c|c|c|}
\hline \multirow[t]{2}{*}{ Infauna species } & \multirow[t]{2}{*}{ Start of experiment } & \multicolumn{3}{|c|}{ End of experiment } \\
\hline & & $\begin{array}{l}\text { High abundance of } \\
\text { C. maenas (Cage I) }\end{array}$ & $\begin{array}{l}\text { Low abundance of } \\
\text { C. maenas (Cage II) }\end{array}$ & Control area \\
\hline Corophium volutator & $6997(1265)$ & 0 & $1626(362)$ & 917 (153) \\
\hline Capitella capitata & $1376(348)$ & $653(95)$ & $1015(97)$ & $584(92)$ \\
\hline Hydrobia spp. & 695 (223) & $1070(709)$ & 2641 (1251) & $778(167)$ \\
\hline Cardium edule & 8410 (1293) & $514(37)$ & 598 (153) & $139(41)$ \\
\hline Mya arenaria & $12552(2377)$ & 0 & 42 (9) & $167(40)$ \\
\hline Spisula subtruncata & 4031 (737) & $1195(167)$ & $417(69)$ & 0 \\
\hline Oligochaeta & $1432(128)$ & $1154(258)$ & $1710(136)$ & $834(78)$ \\
\hline Total ind $0.5 \mathrm{~m}^{-2}$ & 41259 (11789) & 5467 (1567) & $9406(2072)$ & $4059(166)$ \\
\hline Number of species & 18 & 16 & 17 & 12 \\
\hline
\end{tabular}

from start, but decreased successively (Table 5). In the control area, $S$. subtruncata disappeared before the experiment was finished, but $C$. edule was still found in October. In October the mean biomass of the bivalves was $540 \mathrm{~g}$ wet weight $0.5 \mathrm{~m}^{-2}$ in the cages compared to $0.1 \mathrm{~g}$ in the control area. In October, the number of species had decreased in the control area compared to June, while they were about the same inside the cages. The highest density of animals was found in the cage having few crabs.

In conclusion, when using caging to achieve exclusion of epibenthic predators, most infaunal species achieved higher population densities inside the cages than in the control area. An invasion of predators in form of planktonic crab larvae, a problem earlier discussed by Young et al. (1976), Arntz (1977) and Virnstein (1978), indicated that the rate of juvenile infaunal population reduction was related to the number of juvenile crabs.

Thus, epibenthic predators must be considered as important regulators of the infaunal community, a conclusion supported by the data from the stomach analyses of the epibenthic fauna presented above.

\section{Adult-juvenile interactions}

The influence of established infaunal populations on newly settled larvae has been discussed by many authors, e.g. Smidt (1951), Thorson (1957), Woodin (1976) and Peterson (1979). A principal conclusion of this literature is that larvae are in some way attracted to a sediment by the presence of adult animals. Some authors found that larvae could be directly attracted to settle by the presence of populations of their own species (Knight-Jones 1951, Thorson 1952) while others have suggested that larval settlement could be due to the presence of particular microorganisms (Wilson 1953, Woodin 1976).
A prerequisite condition when studying causal mechanisms for spat recruitment or survival is to have reliable sampling methods collecting all sizes of the spat. Theorizing on these mechanisms based on information obtained from samples retained in sieves of $1 \mathrm{~mm}$ or even larger will not of course give complete information concerning adult-juvenile interactions.

\section{Adult-juvenile interactions of bivalves in natural habitat}

Following the severe winter of $1978 / 79$, all adult bivalves in Gullmarsvik were eliminated down to at least $1 \mathrm{~m}$ water depth. Without interactions from adult bivalves, the subsequent recruitment and settlement of the bivalve spat was extremely high with mean abundances of almost 500000 ind $\mathrm{m}^{-2}$ and a biomass value of $3.7 \mathrm{~g} \mathrm{ADW}$ of Mya arenaria. During the spat recruitment in mid 1980, there still remained about 4000 overwintered 1 -group $M$. arenaria $\mathrm{m}^{-2}$. Probably due to competition for space a mean spat abundance of only 13000 ind $\mathrm{m}^{-2}$ were found this year, with a mean biomass of $0.03 \mathrm{~g} \mathrm{ADW}$ (Fig. 5 \& 8). The following year, however, the adult $M$. arenaria had decreased to about 100 ind $\mathrm{m}^{-2}$ but because of growth the same biomass as in previous years was maintained (Fig. 8). Thus, the spat were offered more space for recruitment on the surface sediment than in the preceding year and consequently the spat density in 1981 was found to be of the same magnitude as for other normal years.

Thus, there seem to be some effective mechanisms preventing successful settlement and survival. Suspension feeders are known to filter particles out of the water column and, as suggested by Korringa (1941), Thorson (1950) and Hancock (1970), the mortality of settling spat might be due to such filtration. On the other hand, bivalve larvae have also been shown to pass alive through the mantle cavity and digestive 


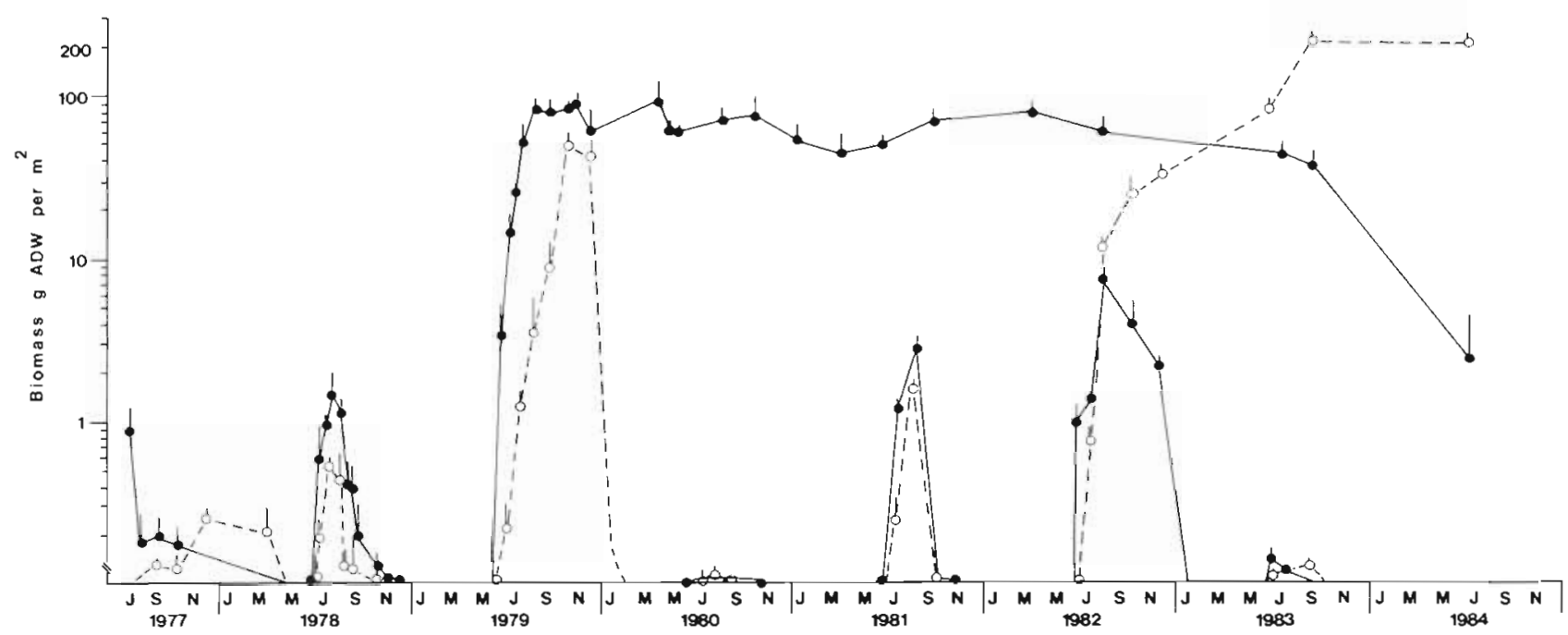

Fig. 8. Mya arenaria ( $\bullet$ ) and Cardium edule (O). Mean biomass (g ADW m ${ }^{-2}$ with SE) in the outer area (50 to $100 \mathrm{~cm}$ water depth) of Gullmarsvik from 1977 to 1984

tract of adult bivalves (Mileikovsky 1974 and references therein). Once the spat are settled on the sediment surface they might be subjected to environmental stress from the siphons of adult bivalves. Kristensen (1957) found that Cardium edule larvae were inhaled by adults, wrapped in mucus and then discharged as pseudofeces, which, according to the author, could cause a significant mortality to juveniles less than $1 \mathrm{~mm}$.

The reasons for the high recruitment of bivalve spat in 1979 compared to e.g. 1978 and 1981 are not to be explained by higher amounts of larvae in the water mass outside the bay. According to mesozooplankton samples (taken with vertical hauls by L. Hernroth, Kristineberg Marine Biological Station, from bottom to surface, with a standard UNESCO WP II $90 \mu \mathrm{m}$ net) the mean maximum number of bivalves (>125 $\mu \mathrm{m}$ ) were about the same during the recruitment period these years, varying only between 27000 and 30000 ind $\mathrm{m}^{-2}$.

A similar pattern of adult-juvenile interactions to that seen during 1980 seemed to appear after the relatively warm winter $1982 / 83$ when a Cardium edule population of 1800 ind $\mathrm{m}^{-2}$ survived, and the settlement of young $C$. edule and Mya arenaria was considerably less than in other years (Fig. 5). As in the years 1980 and 1981, the juveniles had a low survival and in September all $M$. arenaria had disappeared while a few juvenile $C$. edule $\mathrm{m}^{-2}$ still remained.

Thus, the results imply a strong negative interaction between adult and juvenile Mya arenaria and Cardium edule. The reason for bivalve populations being dominated by specific age classes could be a result of the low survival of young bivalves caused by inter- and intraspecific competition. The dominance of specific age classes within bivalve populations has also been reported by e.g. Fitch (1965) and Evans (1977).

\section{Adult-juvenile interactions from experimental studies}

As emphasized by Williams (1980), many authors unfortunately have theorized on causal mechanisms for settlement, recruitment and survival based on information gained from individuals retained on $1 \mathrm{~mm}$ or even larger sieve mesh sizes (Fitch 1965, Hancock 1973, Woodin 1976). A field experiment with controlled manipulation of different densities of adult $M y a$ arenaria was performed in Gullmarsvik, with the intention of investigating whether the effectiveness of adult-juvenile interactions was dependent upon the abundance of adults. The clams used were 3 yr old with a mean length of $50 \mathrm{~mm}$. The densities of adult $M$. arenaria were 0,10 and 100 ind $0.5 \mathrm{~m}^{-2}$. In order to include also the effect of predation from epibenthic mobile animals on juvenile bivalves, both uncaged and caged areas were manipulated.

Treatment with uncaged areas. The experiment was started just before the settlement of bivalves occurred in June and was continued for $49 \mathrm{~d}$ (Table 6). Generally, fewer juvenile clams settled in the areas having adult Mya arenaria than in the area without adults. Without adult bivalves interacting, the maximum abundance of settled bivalves was, at the beginning of the settlement, up to 8 times higher compared to areas having adults. The bivalve settlement was dominated in numbers by $M$. arenaria followed by Cardium edule. The tendency for having larger spat when few adults were present was not consistent for the sporadically occurring bivalve species (Spisula subtruncata and Mytilus edulis). 
Table 6. Mean number of spat bivalves per $0.5 \mathrm{~m}^{2}$ in uncaged areas having different abundances of adult Mya arenaria. (Number of spats are recalculated from an area of $16 \mathrm{~cm}^{2}$ to $0.5 \mathrm{~m}^{2}$ )

\begin{tabular}{|c|c|c|c|c|c|c|c|c|c|c|}
\hline \multirow[t]{2}{*}{ Species } & \multirow[t]{2}{*}{$10 \mathrm{Jun}$} & \multicolumn{3}{|c|}{15 Jun } & \multicolumn{3}{|c|}{28 Jun } & \multicolumn{3}{|c|}{$28 \mathrm{Jul}$} \\
\hline & & $\begin{array}{c}100 \\
\text { ind } \\
0.5 \mathrm{~m}^{-2}\end{array}$ & $\begin{array}{c}10 \\
\text { ind } \\
0.5 \mathrm{~m}^{-2}\end{array}$ & $\begin{array}{c}0 \\
\text { ind } \\
0.5 \mathrm{~m}^{-2}\end{array}$ & $\begin{array}{c}100 \\
\text { ind } \\
0.5 \mathrm{~m}^{-2}\end{array}$ & $\begin{array}{c}10 \\
\text { ind } \\
0.5 \mathrm{~m}^{-2}\end{array}$ & $\begin{array}{c}0 \\
\text { ind } \\
0.5 \mathrm{~m}^{-2}\end{array}$ & $\begin{array}{c}100 \\
\text { ind } \\
0.5 \mathrm{~m}^{-2}\end{array}$ & $\begin{array}{c}10 \\
\text { ind } \\
0.5 \mathrm{~m}^{-2}\end{array}$ & $\begin{array}{c}0 \\
\text { ind } \\
0.5 \mathrm{~m}^{-2}\end{array}$ \\
\hline Mya arenaria & No & 4688 & 6563 & 19531 & 938 & 2188 & 17656 & 2344 & 2031 & 6719 \\
\hline Cardium edule & recruitment & 0 & 0 & 0 & 156 & 313 & 781 & 2188 & 1719 & 4063 \\
\hline Spisula subtruncata & & 0 & 0 & 0 & 0 & 0 & 313 & 0 & 0 & 0 \\
\hline Mytilus edulis & & 0 & 0 & 0 & 0 & 0 & 469 & 156 & 938 & 313 \\
\hline Total number of spat & 0 & 4688 & 6563 & 19531 & 1094 & 2501 & 19219 & 4688 & 4688 & 11095 \\
\hline
\end{tabular}

Treatment with caged areas. The general results of settlement in the cages (Table 7 ) were similar to uncaged-areas with the difference that higher spat abundances were found in the cages. In the caged areas the numbers of settled bivalves on each of the 3 sampling occasions were higher when adult Mya arenaria was absent compared to when present. By the end of July the total number of bivalve juveniles was about $339000.5 \mathrm{~m}^{-2}$ in caged areas without adults compared to $111000.5 \mathrm{~m}^{-2}$ in uncaged areas, i.e. a difference mainly arising from predation by the epibenthic fauna.

The negative correlation found in this experiment between the number of settled spat and the density of adult suspension feeders was also observed by Williams (1980). He found that significantly more clam spat settled in areas with no, or moderate, adult clam abundances than in areas with high adult clam abundances. The reason for this was suggested to be related to the ingestion of larvae by adults and/or a preference of larvae to settle away from the adults. Peterson (1982) also demonstrated a reduction in successful recruitment at high adult densities in mud habitats of a suspension feeding bivalve. In a sand habitat, however, he was unable to demonstrate any significant effect of adult density on the recruitment. The reason for this difference was assumed to be a consequence of differing levels of hydrodynamic energy and resultant differences in sediment mobility. New recruits in sand were supposed to be as mobile as the sandy sediments themselves, such that even a large impact of adults on larvae could be difficult to detect due to sand movements.

Thus, the results of the adult-juvenile field experiments indicate an effect of established Mya arenaria upon the settling bivalve spat. This suggests that the adult-juvenile interaction is an important factor influencing the densities of soft bottom communities in shallow areas. Woodin (1976) suggested a hypothesis that once a dense assemblage is established, few larvae will successfully settle and establish themselves in the assemblage. A high survival of adults, however, does not seem to completely prevent settlement, as thousands of juveniles per $\mathrm{m}^{2}$ are usually found between the established adults during the recruitment period in Gullmarsvik (Table 2; Fig. 5). During years when bivalve survival was high, as in 1980 for $M$. arenaria and 1983 for Cardium edule, spat recruitment was significantly lower than other years, with mean biomasses of less than $0.1 \mathrm{~g} \mathrm{ADW} \mathrm{m}^{-2}$ (Fig. 8). Indi-

Table 7. Mean number of spat bivalves per $0.5 \mathrm{~m}^{2}$ in caged areas having different abundances of adult Mya arenaria. (Number of spats are recalculated from an area of $16 \mathrm{~cm}^{2}$ to $0.5 \mathrm{~m}^{2}$ )

\begin{tabular}{|c|c|c|c|c|c|c|c|c|c|c|}
\hline \multirow[t]{3}{*}{ Species } & \multirow[t]{3}{*}{$10 \mathrm{Jun}$} & \multicolumn{3}{|c|}{15 Jun } & \multicolumn{3}{|c|}{28 Jun } & \multicolumn{3}{|l|}{$28 \mathrm{Jul}$} \\
\hline & & 100 & 10 & 0 & 100 & 10 & 0 & 100 & 10 & 0 \\
\hline & & $\begin{array}{c}\text { ind } \\
0.5 \mathrm{~m}^{-2}\end{array}$ & $\begin{array}{c}\text { ind } \\
0.5 \mathrm{~m}^{-2}\end{array}$ & $\begin{array}{c}\text { ind } \\
0.5 \mathrm{~m}^{-2}\end{array}$ & $\begin{array}{l}\text { ind } \\
0.5 \mathrm{~m}^{-2}\end{array}$ & $\begin{array}{c}\text { ind } \\
0.5 \mathrm{~m}^{-2}\end{array}$ & $\begin{array}{l}\text { ind } \\
0.5 \mathrm{~m}^{-2}\end{array}$ & $\begin{array}{c}\text { ind } \\
0.5 \mathrm{~m}^{-2}\end{array}$ & $\begin{array}{l}\text { ind } \\
0.5 \mathrm{~m}^{-2}\end{array}$ & $\begin{array}{l}\text { ind } \\
0.5 \mathrm{~m}^{-2}\end{array}$ \\
\hline Mya arenaria & No & 6406 & 11563 & 23438 & 2188 & 12813 & 29219 & 6094 & 13125 & 19998 \\
\hline Cardium edule & recruitment & 0 & 0 & 0 & 469 & 1719 & 1250 & 5625 & 6563 & 11094 \\
\hline Spisula subtruncata & & 0 & 0 & 0 & 0 & 938 & 1719 & 0 & 313 & 625 \\
\hline Mytilus edulis & & 0 & 0 & 0 & 469 & 313 & 2344 & 1250 & 781 & 2188 \\
\hline Total number of spat & 0 & 6406 & 11563 & 23438 & 3126 & 15783 & 34532 & 12969 & 20782 & 33905 \\
\hline
\end{tabular}


viduals of these spats never even reached a size larger than $2 \mathrm{~mm}$ and when juvenile recruitment ceased in August, the 0-group population decreased and was soon eliminated. This elimination could be due to competition for space and food as well as predation. When comparing numbers of spat in caged and uncaged areas, the significance of predation from the mobile epibenthic predators was suggested by the higher number of individuals within the caged areas.

\section{Interactions between adult bivalves}

From 1977 to 1983 the spat recruitment of Mya arenaria and Cardium edule was studied. During all the years investigated the number of recruits was higher for $M$. arenaria than for $C$. edule (Fig. 5). A corresponding tendency was also found in the biomass, except in 1982 when the biomass of $C$. edule exceeded that of $M$. arenaria from mid August (Fig. 8). August 1982 was found to be the warmest month of all during the period 1977-1984, with a mean temperature of $19.8^{\circ} \mathrm{C}$ (Fig. 2). This combined with other favourable environmental factors such as food availability probably resulted in a faster growth rate. Thus, $C$. edule rapidly became too large for several predators (Moller \& Rosenberg 1983). During 1983 the upper $5 \mathrm{~cm}$ of the sediment was completely covered by $C$. edule belonging to the 1982 year class and the increasing biomass of $C$. edule resulted in a continuous decrease in both abundance and biomass of $M$. arenaria. From an average biomass for this clam of about $80 \mathrm{~g} \mathrm{ADW} \mathrm{m}^{-2}$ during the period 1979-1982, only a few $\mathrm{g} \mathrm{m}^{-2}$ was found in July 1984 corresponding to a mean abundance of $0.2 \mathrm{~m}^{-2}$. Probably the siphons of $M$. arenaria had difficulty in reaching the sediment surface due to the thick carpet of $C$. edule, thus producing high mortality amongst the $M$. arenaria.

Peterson (1979) questioned some beliefs about the role and modes of interspecific competition in soft sediment systems. Although both the distributional and experimental evidence suggested that interspecific competition played a significant role in the organization of many shallow-water infaunal communities, there were no studies, according to Peterson (1979), demonstrating the active process of competitive exclusion in which one species actually eliminated another

The study of interspecific competition in a natural habitat between Mya arenaria and Cardium edule in Gullmarsvik, however, has demonstrated a significant impact, where one species almost completely eliminated another species for some time. Although the initially established adult $M$. arenaria seemed to be able to prevent large bivalve settlements for many years, they could not impede the rapidly growing $C$. edule population in 1982 resulting in the elimination mentioned above.

Thus, interspecific competition played an important role in influencing dominance between 2 species, which in this case ended with the elimination of the initially dominant species.

Acknowledgements. I am grateful to my colleagues Tom Pearson, Leif Pihl and Rutger Rosenberg for discussions and for critically reading the manuscript. Financial support was given by the Swedish Environment Protection Board which is greatly acknowledged

\section{LITERATURE CITED}

Ambrose, W. G. (1984). Role of predatory infauna in structuring marine soft-bottom communities. Mar. Ecol. Prog. Ser. 17: 109-115

Arntz, W. E. (1977). Results and problems of an 'unsuccessful' benthos cage predation experiment. In: Keegan, B. F., Ceidigh, P. O., Boaden, P. J. S. (ed.) Biology of benthic organisms. Pergamon Press, New York, p. 31-44

Arntz, W. E. (1981). Entwicklung von marinen Bodentiergemeinschaften bei Ausschluß von Räubern: Nur Artefakte? Meeresforschung 28: 189-204

Arntz, W. E., Rumohr, H. (1982). An experimental study of macrobenthic colonization and succession, and the importance of seasonal variation in temperature latitudes. J. exp. mar Biol. Ecol. 64: 17-47

Beukema, J. J. (1973). Migration and secondary spatfall of Macoma balthica (L.) in the western part of the Wadden Sea. Neth. J. Zool. 23: 356-357

Beukema, J. J. (1979). Biomass and species richness of the macrobenthic animals living on a tidal flat in the Dutch Wadden Sea: effects of a severe winter. Neth. J. Sea Res. 13: 203-223

Beukema, J. J. (1982). Annual variation in reproductive success and biomass of the major macrozoobenthic species living in a tidal flat area of the Wadden Sea. Neth. J. Sea Res. 16: $37-45$

Blegvad, H. (1928). Quantitative investigations of bottom invertebrates in the Limfjord 1910-1927 with special reference to the plaice-food. Rep. Dan. Biol. Stn 34: 33-52

Evans, S. (1977). Growth, production, and biomass release of a non-stable population of Cardium edule L. (Bivalvia). Zoon 5: 133-141

Fauchald, K., Jumars, P. A. (1977). The diet of worms: a study of polychaete feeding guilds. Oceanogr. mar. Biol. A. Rev. 17: $193-284$

Fenchel, T., Kofoed, L. H. (1976). Evidence for exploitative interspecific competition in mud snails (Hydrobiidae). Oikos 27: 367-376

Fitch, J. E. (1965). A relatively unexploited population of Pismo clams Tivela stultorum (Mawe, 1923). Proc. malac. Soc. Lond. 36: 309-312

Håkanson, L., Jansson, M. (1983). Principles of lake sedimentology. Springer-Verlag, Heidelberg, p. 316

Hancock, D. A. (1970). The role of predators and parasites in a fishery for the mollusc Cardium edule L. In: den Boer, P. J., Gradwell, G. R. (ed.) Dynamics of numbers in populations. Proc. Adv. Study Inst. (Oosterbeek), p. 419-439

Hancock, D. A. (1973). The relationship between stock and recruitment in unexploited invertebrates. Rapp. P.-v. Réun. Cons. int. Explor. Mer. 164: 113-131 
Hulings, N. C., Gray, J. S. (1976). Physical factors controlling abundance of meiofauna on tidal and atidal beaches. Mar. Biol. 34: 77-83

Knight-Jones, E.W. (1951). Aspects of the settling behaviour of larvae of Ostrea edulis on Essex oyster beds. Rapp. P.-v. Réun. Cons. perm. int. Explor. Mer. 128: 30-34

Korringa, P. (1941). Experiments and observations on swarming, pelagic life and settling in the European flat oyster Ostrea edulis L. Archs néerl. Zool. 5: 1-249

Kreger, D. (1940). On the ecology of Cardium edule. Archs néerl. Zool. 4: 157-200

Kristensen, J. (1957). Differences in density and growth in a cockle population in the Dutch Wadden Sea. Archs néerl. Zool. 12: 351-453

Levinton, J. S. (1977). Ecology of shallow water deposit-feeding communities, Quisset Harbor, Massachusetts. In: Coull, B. C. (ed.) Ecology of marine benthos. Univ. S. Carolina Press, Columbia, p. 191-227

Lewis, F. G. Ill., Stoner, A. W. (1983). Distribution of macrofauna within seagrass beds: an explanation for patterns of abundance. Bull. mar. Sci. 33: 296-304

Marsh, G. A. (1973). The Zostera epifaunal community in the York River, Virginia. Chesapeake Sci. 14: 87-97

Mileikovsky, S. A. (1974). On predation of pelagic larvae and early juveniles of marine bottom invertebrates by adult benthic invertebrates and their passing alive through their predators. Mar. Biol. 26: 303-311

Möller, P. (1985). Production and abundance of juvenile Nereis diversicolor, and oogenic cycle of adults in shallow waters of western Sweden. J. mar. biol. Ass. U.K. 65: 603-616

Möller, P., Pihl, L., Rosenberg, R. (1985a). Fish and bottom fauna in Swedish shallow waters in the Skagerrak and the Kattegat. In: Rosenberg, R. (ed.) Biological assessment of Swedish shallow marine areas. Fish and bottom fauna. Swedish Environm. Protection Bd PM 1911, p. 7-95 (in Swedish, English summary)

Möller, P., Pihl, L., Rosenberg, R. (1985b). Benthic faunal energy flow and biological interaction in some shallow marine soft bottom habitats. Mar. Ecol. Prog. Ser. 27 : 109-121

Möller, P., Rosenberg, R. (1982). Production and abundance of the amphipod Corophium volutator on the west coast of Sweden. Neth. J. Sea Res. 16: 127-140

Möller, P., Rosenberg, R. (1983). Recruitment, abundance and production of Mya arenaria and Cardium edule in marine shallow waters, western Sweden. Ophelia 22: 33-55

Muus, K. (1973). Settling, growth and mortality of young bivalves in the Oresund. Ophelia 12: 79-116

Nelson, G. N. (1980). The biology of eelgrass (Zostera marina L.) amphipods. Crustaceana 39: 59-89

Orton, J. H. (1926). On the rate of growth of Cardium edule. Part I. Experimental observations. J. mar biol. Ass. U.K. 14: $239-279$

Orth, R. J. (1973). Benthic infauna of eelgrass, Zostera marina. beds. Chesapeake Sci. 14: 258-269

Orth, R. J. (1977). The importance of sediment stability in seagrass communities. In: Coull, B. C. (ed.) Ecology of marine benthos. Univ. South Carolina Press, Columbia, p. 281-300

Petersen, C. G. J. (1918). The sea bottom and its production of fish food. A survey of the work done in connection with the valuation of the Danish waters from 1883-1917. Rep. Dan. Biol. Stn 25: 1-62

Peterson, C. H. (1979). Predation, competitive exclusion, and diversity in the soft-sediment benthic communities of estuaries and lagoons. In: Livingstone, R. J. (ed.) Ecologi- cal processes in coastal and marine systems. Plenum Press, New York, p. 233-264

Peterson, C. H. (1982). The importance of predation and intraand interspecific competition in the population biology of two infaunal suspension-feeding bivalves, Protothaca staminea and Chione undatella. Ecol. Monogr. 52: $437-475$

Peterson, C. H., Andre, S. V. (1980). An experimental analysis of interspecific competition among marine filter feeders in a soft-sediment environment. Ecology 61: 129-139

Pihl, L. (1982). Food intake of young cod and flounder in a shallow bay on the Swedish west coast. Neth. J. Sea Res 15: $419-432$

Pihl, L. (1985). Food selection and consumption of mobile epibenthic fauna in shallow marine areas. Mar. Ecol. Prog Ser. 22: 169-179

Pihl, L., Rosenberg, R. (1982). Production, abundance and biomass of mobile epibenthic marine fauna in shallow waters, western Sweden. J. exp. Mar. Biol. Ecol. 57 : 273-301

Pihl, L., Rosenberg, R. (1984). Food selection and consumption of the shrimp Crangon crangon in some shallow marine areas in western Sweden. Mar. Ecol. Ptog. Ser. 15 159-168

Reise, K. (1977a). Predation pressure and community structure of an intertidal soft-bottom fauna. In: Keegan, B. F. Ceidigh, P. O., Boaden, P. J. S. (ed.) Biology of benthic organisms. Pergamon Press, New York, p. 513-519

Reise, K. (1977b). Predation exclusion experiments in an intertidal mud flat. Helgoländer Meeresunters. 30 : $263-271$

Reise, K. (1978). Experiments on epibenthic predation in the Wadden Sea. Helgoländer Meeresunters. 31: 55-101

Santos, S. L., Simon, J. L. (1974). Distribution and abundance of the polychaetous annelids in a south Florida estuary. Bull. mar. Sci. 24: 669-689

Segerstråle, S. G. (1962). Investigations on Baltic populations of the bivalve Macoma balthica (L.). Part II. What are the reasons for the periodic failure of recruitment and the scarcity of Macoma in the deeper waters of the inner Baltic? Soc. Sci. Fenn. Comment. Biol. 24: 1-26

Smidt, E. L. B. (1944). The effects of ice winters on marine littoral faunas. Folia geogr. dan. 2: 1-36

Smidt, E. L. B. (1951). Animal production in the Danish Waddensea. Meddr Kommn. Danm. Fisk.-og Havunders., Ser. Fiskeri 11: 1-151

Stoner, A. W. (1980). The role of seagrass biomass in the organization of benthic macrofaunal assemblages. Bull. mar. Sci. 30: 537-551

Summerson, H. C., Peterson, C. H. (1984). Role of predation in organizing benthic communities of a temperate-zone seagrass bed. Mar. Ecol. Prog. Ser. 15: 63-77

Thandrup, H. M. (1935). Beiträge zur Okologie der Wattenfauna auf experimenteller Grundlage. Meddr Kommn. Danm. Fisk.-og Havunders., Ser. Fiskeri 10: 1-125

Thorson, G. (1950). Reproductive and larval ecology of marine bottom invertebrates. Biol. Rev. 25: 1-45

Thorson, G. (1952). Zur jetzigen Lage der marinen BodentierOkologie. Verh. dt. zool. Ges.: 276-327

Thorson, G. (1957). Bottom communities (sublittoral or shallow shelf). In: Hedgpeth, J.W. (ed.) Treatise on marine ecology and paleoecology. Geol. Soc. Am. Memoir 67, 1: $461-534$

Thorson, G. (1966). Some factors influencing the recruitment and establishment of marine benthic communities. Neth. J. Sea Res. 3: 267-293

Virnstein, R. W. (1977). The importance of predation by crabs 
and fishes on benthic infauna in Chesapeake Bay. Ecology 58: 1199-1217

Virnstein, R. W. (1978). Predator caging experiments in soft sediments: caution advised. In: Wiley, M. L. (ed.) Estuarine interactions. Academic Press, New York, p. 261-273

Virnstein, R. W. (1979). Predation on estuarine infauna: response patterns of component species. Estuaries 2: 69-86

Virnstein, R. W., Nelson, W. G., Lewis III., F. G., Howard, R. K. (1984). Latitudinal patterns in seagrass epifauna: do patterns exist, and can they be explained? Estuaries 7 : $310-330$

Weinberg, J. R. (1984). Interactions between functional groups in soft-substrata: Do species differences matter? J. exp. mar. Biol. Ecol. 80: 11-28

Whitlatch, R. B. (1980). Patterns of resource utilization and coexistence in marine intertidal deposit-feeding communities. J. mar. Res. 38: 743-765

Williams, J. G. (1980). The influence of adults on the settlement of spat of the clam, Tapes japonica. J. mar. Res. 38: $729-741$
Wilson, D. P. (1953). The settlement of Ophelia bicornis Savigny larvae. J. mar. biol. Ass. U.K. 31: 413-438

Woodin, S. A. (1974). Polychaete abundance patterns in a marine soft-sediment environment: the importance of biological interactions. Ecol. Monogr. 44: 171-187

Woodin, S. A. (1976). Adult-larval interactions in dense infaunal assemblages: patterns of abundance. J. mar. Res. 34: $25-41$

Young, D. K., Buzas, M. A., Young, M. W. (1976). Species densities of macrobenthos associated with seagrass: a field experimental study of predation. J. mar Res. 34: $577-592$

Young, D. K., Young, M. W. (1977). Community structure of the macrobenthos associated with seagrass of the Indian River estuary, Florida. In: Coull, B. C. (ed.) Ecology of marine benthos. Univ. South Carolina Press, Columbia, p. 359-381

Young, D. K., Young, M. W. (1978). Regulation of species densities of seagrass-associated macrobenthos: Evidence from field experiments in the Indian River estuary, Florida. J. mar. Res. 36: 569-593 